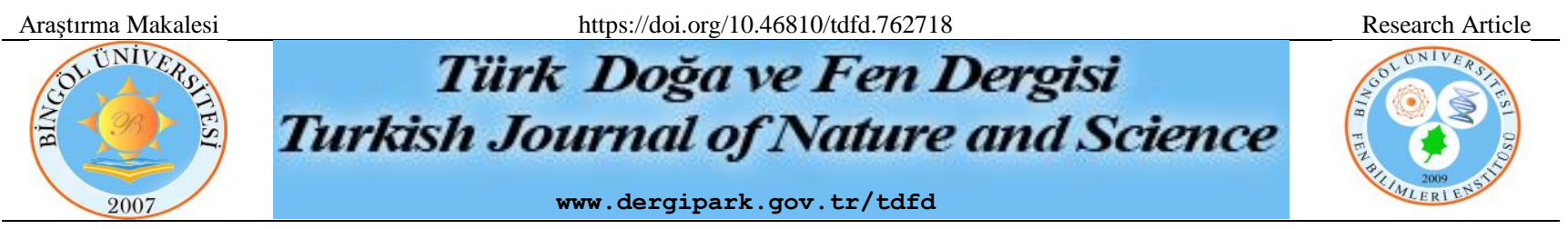

\title{
Bingöl Şartlarında Bazı İtalyan Çimi (Lolium Multiflorum Lam.) Çeşitlerinin Ot Verimi ve Kalitesinin Belirlenmesi
}

\author{
Vural LALE ${ }^{1}$, Kağan KÖKTEN ${ }^{2 *}$ \\ ${ }^{1}$ Bingöl Üniversitesi, Fen Bilimleri Enstitüsü, Tarla Bitkileri ABD, 12000 Bingöl, Türkiye \\ ${ }^{2}$ Bingöl Üniversitesi, Ziraat Fakültesi, Tarla Bitkileri Bölümü, 12000 Bingöl, Türkiye \\ Vural LALE ORCID: 0000-0003-0119-0910 \\ Kağan KÖKTEN ORCID: 0000-0001-5403-5629
}

*Sorumlu Yazar: kkokten@bingol.edu.tr

(Alınış: 02.07.2020, Kabul: 12.10.2020, Online Yayınlanma: 23.10.2020)

\begin{abstract}
Anahtar
Kelimeler

Lolium

multiflorum,

İtalyan çimi,

ADF,

NDF,

Ham protein,

Ot verimi.
\end{abstract}

Öz: $\mathrm{Bu}$ araştırma, Bingöl ekolojik koşullarında yetiştirilecek İtalyan çimi çeşitlerinin verim ve kalite özelliklerinin tespit edilmesi amacıyla 2018 y1lı yetiştirme sezonunda kurulmuştur. Araştırmada, 6 adet İtalyan çimi çeşidi (Devis, Baqueano, Caramba, Vallivert, Trinova, Vespolini) bitki materyali olarak kullanılmıştır. Çalışma tesadüf blokları deneme desenine göre üç tekrarlamalı olarak yürütülmüştür. Çalışmada; yeşil ot, kuru ot, ham protein verimleri, ham protein oranı, Asit deterjanda çözünmeyen lif (ADF) oranı, nötr deterjanda çözünmeyen lif (NDF) oranı, sindirilebilir kuru madde (SKM) oranı, kuru madde tüketimi (KMT) oranı, nispi yem değeri (NYD)'ne ait veriler ele alınmıştır. Çalışma sonucunda; yeşil ot verimi 3377,33-4457,67 kg/da, kuru ot verimi 808,13$1051,83 \mathrm{~kg} / \mathrm{da}$, ham protein oran $\% 17,58-21,13$, ham protein verimi $154,00-179,57 \mathrm{~kg} / \mathrm{da}$, ADF oran1 \%38,33-40,67, NDF oran1 \%55,00-63,37, SKM oran1 \%57,22-\%59,04, KMT oran1 \%1,8932,183 ve NYD 86,44-99,55 arasında değişmiştir. Araştırmada, incelenen ADF ve SKM oranları dışındaki tüm özellikler bakımından çeşitler arasında farklılıklar belirlenmiştir. En fazla yeşil ot verimi Trinova çeşidinde, en fazla kuru ot verimi, KMT oranı ve NYD Vallivert çeşidinde, en fazla ham protein oranı Vespolini çeşidinde, en az NDF oranı Vallivert çeşidinde, en fazla ham protein verimi ve SKM oranı Baqueano çeşidinde, en az ADF oranı Baqueano çeşidinde tespit edilmiştir. Elde edilen bu sonuçlar neticesinde; Bingöl ekolojik koşulları için yeşil ot ve ham protein verimleri bakımından Baqueano çeşidinin, NDF, KMT oranları ve NYD bakımından ise Vallivert çeşidinin ekilmesi önerilmektedir.

\section{Determination of Herbage Yield and Quality of some Italian Ryegrass (Lolium Multiflorum Lam.) Varieties in Bingol Conditions}

Keywords
Lolium
multiflorum,
Italian
ryegrass,
ADF,
NDF,
Crude
protein,
Herbage
yield.

Keywords

Lolium multiflorum, Italian ryegrass, ADF, NDF, Crude Herbage yield.

\begin{abstract}
This research was carried out in 2018 growing season in order to determine yield and quality characteristics of Italian grass varieties to be grown in Bingol ecological conditions. In this research, 6 Italian grass varieties (Devis, Baqueano, Caramba, Vallivert, Trinova, Vespolini) were used as plant material. This research was established in randomized block design with three replications. In the study; green herbage yield, dry herbage yield, crude protein ratio, crude protein yield, acid detergent fiber (ADF) ratio, nötral detergent fiber (NDF) ratio, digestible dry matter (DDM) ratio, dry matter intake (DMI) ratio and relative feed value (RFV) were obtained. As a result of the research; green herbage yield 3377.33-4457.67, kg/da, dry herbage yield 808.13$1051.83 \mathrm{~kg} / \mathrm{da}$, crude protein ratio $17.58-21.13 \%$, crude protein yield 154.00-179.57 kg/da, ADF ratio $38.33-40.67 \%$, NDF ratio 55.00-63.37\%, DDM ratio 57.22-59.04\%, DMI ratio 1.893-2.183\% and RFV ranged from 86.44-99.55. In this study, differences were determined between the varieties in terms of all the features except the ADF and DDM ratios examined. Highest green herbage yield in Trinova variety; highest dry herbage yield, DMI ratio and RFV in Vallivert variety; highest crude protein ratio in Vespolini variety, lowest NDF ratio in Vallivert variety, highest crude protein yield and DDM ratio and lowest ADF rate was obtained in Baqueano variety. According to these results; it is recommended to plant Baqueano variety in terms of green herbage and crude protein yields, and Vallivert variety in terms of NDF, DMI ratios with RFV for Bingol ecological conditions.
\end{abstract}




\section{GİRIŞ}

İtalyan çimi (Lolium multiflorum Lam.) Poales takımının Poaceae familyasina ait Lolium cinsi taksonomisine sahip bitki, tarla özellikleri yönünden çabuk gelişmesi, bolca yeşil ot üretilmesi ve sulanan arazilerde gübrelemeye pozitif eldeler vermesi ve çok ylllık olmaması sebebiyle ekim nöbetine girerek üretimi hızla artacak bir yem bitkisidir. İngiltere'de İtalyan çimi, süt ineklerinin beslenmesi ve silaj yemi yapmak amaciyla üretilmekte, ayrıca bitkiler çok fazla kök gelişimi oluşturduğu için toprağın organik maddesini arttırmak amaciyla uygun olmayan arazilerin sslah edilmesi için yetiştirilmektedir [1]. İtalyan çimi dünyanın birçok ülkesinde yem bitkisi olarak kullanılmaktadır. Silaj yapmak ve kuru ot üretmek amacıyla yaygın bir şekilde yetiştirilmektedir. Pek çok üretici İtalyan çimini hayvanlarını otlatmak amaciyla suni mera tesisinde kullanmaktadırlar. Bitki, yüksek protein ve enerji değerine sahiptir. Bitki içeriğinde bulunan şeker ve kolay sindirilebilme özelliği nedeniyle hayvanlar tarafindan sevilerek tüketilmektedir. Yaprakları koyu yeşil ve parlaktır. Sonbahar, kış ve ilkbahar aylarında oldukça iyi bir büyüme gösterir ve bitkinin yaprakları oldukça geniştir. Kar yağan bölgelerde gelişmesini sonbahar ve ilkbahar aylarında yapar, kış aylarında ise uyku durumuna girer [2]. İtalyan çimi çiçeklenme periyodu başlangıcında hasat edildiğinde çabuk kurutulabilir ve hayvanlar tarafindan severek yenen kaliteli kuru ot ürünü sağlar. Yağış koşulları nedeniyle biçiminin geciktirilmesi, hasat edilen ürünün silaj olarak hayvanlara yedirilmesinde yarar bulunmaktadır. Bitki her ne kadar ince saplı ve kolay kabalaşmayan bir yapıya sahip olsa da çiçeklenmeden sonraki biçimlerde elde edilen kuru otun sindirilebilirliği düşmektedir. Normal şartlarda, bir biçimle dekardan 1500-2500 kg yeşil ot ve $500-800 \mathrm{~kg} \mathrm{da}^{-1}$ arasında farklılık gösteren kuru ot verimi almak mümkündür. Sulu koşullarda veya ilkbahar yağmurlarının bitki ihtiyacını karşıladığı bölgelerde, 2-3 defa hasat yaparak 4-6 ton da ${ }^{-1}$ yeşil ot, $750-1500 \mathrm{~kg} \mathrm{da}^{-1}$ kuru ot ürün sağlanabilmektedir [3].

Üretimi yapılan bitkilerin; kullanılan çeşitler, rakım, toprak istekleri, iklim, ekim zamanı, ekim sıklığı, sulama, biçim dönemi, adaptasyon vb. faktörlerin bilinçsiz kullanılmasından ötürü adaptasyon ve kalitede ciddi sorunlar oluşmaktadır. $\mathrm{Bu}$ özellikler arasında bulunan adaptasyon yetenekleri, İtalyan çimi yetiştiriciliği üzerine etkilidir. Uygun çeşit veya çeşitlerin saptanması verim ve kalitede oluşacak kayıpları en az düzeye indirecektir. Avrupa kıtasının güney kısımlarından dünyaya yayılan İtalyan çimi, çim cinsi içerisinde, kültürel üretimi yapılan bir vejetasyon dönemi içerisinde yaşamını sürdüren bir bitki türüdür. Ülkemizde son dönemde bu bitki türünün üretilmesi, yem bitkilerinin üretimini artırmak amaciyla devlet tarafindan sağlanan tarımsal teşviklerle birlikte üreticilerin yeni gözdesi olmaya başlamıştır [4].

Bu çalışmanın amacı; Bingöl şartlarında bazı İtalyan çimi (Devis, Baqueano, Caramba, Vallivert, Trinova, Vespolini) çeşitlerinin ot verimi ve kalitesinin belirlenmesidir.

\section{MATERYAL VE METOT}

Araştırma, 2018 yılı Nisan ayının ilk yarısında Bingöl Üniversitesi Araştırma ve Uygulama Alanı'nda yapılmıştır. Bingöl iline ait iklim verileri incelendiğinde, 1975-2015 yılları arasında aylık ortalama sıcaklığının $19,7^{\circ} \mathrm{C}$, toplam yağış miktarının $232,4 \mathrm{~mm}$ ve ortalama nispi nem değerinin ise $\% 45,6$ olduğu tespit edilmiştir. Araştırmanın takip edildiği 2018 yılı üretim periyodunun 1975-2015 y1lları ortalamasından daha sicak $\left(21,6^{\circ} \mathrm{C}\right)$, daha fazla yăğsşlı $(269,7 \mathrm{~mm})$ ve nispi nem değerinin de daha düşük $(\% 44,2)$ olduğu anlaşılmaktadır. Denemenin yapıldığ derinliğinden alınan toprak numuneleri karıştırılarak temsili toprak örneği elde edilmiştir. Elde edilen toprak örneğinin kimyasal analizi Bingöl Üniversitesi Ziraat Fakültesi Toprak Bilimi ve Bitki Besleme Bölümü laboratuvarında yapılmıştır. Analiz sonucuna göre; araştırma alanına ait toprak yapısının (ideal toprak sınıfi) tınlı olduğu saptanmıştır. Knowels ve Watkin [5] tarafindan belirtilen değerler dikkate alınarak toprak analiz verileri incelendiğinde; çalışma alanının pH'sı hafif asidik $(6,57)$, tuzsuz $(\% 0,0315)$, organik madde oranı orta $(\% 1,905)$, kireç oranının düşük $(\% 0,36)$, fosfor $\left(7,9 \mathrm{~kg} \mathrm{da}^{-1}\right)$ ve potasyum $\left(24,51 \mathrm{~kg} \mathrm{da}^{-1}\right)$ açısından yetersiz olduğu görülmektedir.

Çalışmada materyal olarak, Baqueano, Caramba, Devis, Vespolini, Vallivert ve Trinova isimli İtalyan çimi çeşitleri kullanılmıştır. Deneme alanının toprak hazırlığı, 2018 yılı ilkbaharında pulluk ile derin sürüm yapıldıktan sonra kazayağı ve tapan çekilerek ekime hazır hale getirilmiştir. Deneme üç tekerrürlü olarak, tesadüf blokları deneme desenine göre kurulmuştur. Parsel alanı $5 \mathrm{~m}$ uzunluk ve 6 sıra olacak şekilde yapılmıştır. Ekim işlemi $20 \mathrm{~cm}$ sıra aralığında ve dekara $3 \mathrm{~kg}$ tohumluk kullanılarak yapılmıştır. Denemenin yürütüldü̆ğü toprağa ekim ile beraber dekara $4 \mathrm{~kg}$ azot, $10 \mathrm{~kg}$ fosfor $\left(\mathrm{P}_{2} \mathrm{O}_{5}\right)$ olacak biçimde DAP gübresi verilmiştir. Bitkilerin sapa kalkma aşamasında $4 \mathrm{~kg}$ azot takviyesi yapılarak toplam verilen azot miktarı $8 \mathrm{~kg} \mathrm{da}^{-1}$, a tamamlanmıştır. Bitkinin ihtiyaç duyduğu dönemlerde sulama yapılmıştır.

Denemede ekimi yapılan her parselden dişta kalan birer sıra çıkarıldıktan sonra geriye kalan ortadaki dört sıradan biçilen yeşil aksamın ağırlıkları alınmış ve elde edilen ağırlıklar dekar hesabına dönüştürülmüştür. Her parselden alınan $500 \mathrm{~g}$ bitki numunesi, $70{ }^{\circ} \mathrm{C}$ 'de 48 saat kurumaya bırakıldıktan sonra tartılarak kuru madde oranı tespit edilmiştir. Daha sonra kuru madde oranları ile yeşil ot verimi birbiri ile çarpılıp kuru ot verimi belirlenmiştir. İtalyan çiminin azot $(\mathrm{N})$ içeriği Kjeldahl yöntemi ile belirlenmiştir. Elde edilen azot oranı 6,25 ile çarpılarak ham protein oranı elde edilmiştir [6]. Ham protein verimi, kuru ot verimi ile ham protein oranının çarpılması ile elde edilmiştir. NDF ve ADF oranı [7] ANKOM 200 Fiber Analyzer (ANKOM Technology Corp. Fairport, NY, USA) cihazı kullanılarak elde edilmiştir. Elde edilen ADF oranı ile sindirilebilir kuru madde $(\mathrm{SKM}=88,9-(0,779 \mathrm{x} \% \mathrm{ADF}))$ miktarları, NDF oranı ile kuru madde tüketimi $(\mathrm{KMT}=120 /(\% \mathrm{NDF})$ ), SKM ve KMT değerleri ile de nispi yem değeri (NYD= SKM x KMT) /1,29) hesaplanmıștır [8]. 
Denemeden saptanan veriler JMP istatistik paket programı yardımıyla LSD testi yapılarak farklılıklar ve benzerlikler karşılaştırılmıştır.

\section{BULGULAR}

\subsection{Yeşil Ot, Kuru Ot ve Ham Protein Verimleri (kg $\mathrm{da}^{-1}$ ) ile Ham Protein Oranı (\%)}

Tablo 1. İtalyan çimi çeşitlerinde saptanan yeşil ot, kuru ot ve ham protein verimi ile ham protein oranlarına ait ortalama değerler

\begin{tabular}{|l|l|l|l|l|}
\hline Çeşitler & Yeşil Ot Verimi $\left(\mathbf{k g ~ d a}^{-1}\right)$ & Kuru Ot Verimi $\left(\mathbf{k g ~ d a}^{-1}\right)$ & Ham Protein Oranı $(\%)$ & Ham Protein Verimi $\left(\mathbf{k g}\right.$ da $\left.^{-1}\right)$ \\
\hline Devis & $3701,05 \mathrm{C}^{* *}$ & $1044,20 \mathrm{~A}^{* *}$ & $16,73 \mathrm{C}^{* *}$ & $174,77 \mathrm{~A}^{*}$ \\
\hline Baqueano & $4417,83 \mathrm{~A}$ & $939,97 \mathrm{~B}$ & $19,10 \mathrm{~B}$ & $179,57 \mathrm{~A}$ \\
\hline Caramba & $4172,50 \mathrm{AB}$ & $1031,93 \mathrm{~A}$ & $16,87 \mathrm{C}$ & $174,17 \mathrm{AB}$ \\
\hline Vallivert & $3377,33 \mathrm{D}$ & $1051,83 \mathrm{~A}$ & $14,63 \mathrm{D}$ & $154,00 \mathrm{C}$ \\
\hline Trinova & $4457,67 \mathrm{~A}$ & $929,43 \mathrm{~B}$ & $17,00 \mathrm{C}$ & $157,80 \mathrm{BC}$ \\
\hline Vespolini & $4043,00 \mathrm{~B}$ & $808,13 \mathrm{C}$ & $21,13 \mathrm{~A}$ & $170,70 \mathrm{ABC}$ \\
\hline Ortalama & $\mathbf{4 0 2 8 , 3 1}$ & $\mathbf{9 6 7 , 5 8}$ & $\mathbf{1 7 , 5 8}$ & $\mathbf{1 6 8 , 5 0}$ \\
\hline
\end{tabular}

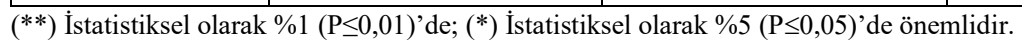

Tablo 1 incelendiğinde, en yüksek yeşil ot verimi $4457,67 \mathrm{~kg} \mathrm{da}^{-1}$ ile Trinova çeşidinden saptanırken, bunu istatistiki olarak aynı grupta bulunan Baqueano (4417,83 $\left.\mathrm{kg} \mathrm{da}{ }^{-1}\right)$ ile Caramba $\left(4172,50 \mathrm{~kg} \mathrm{da}^{-1}\right)$ çeşitleri takip etmiştir. En düşük yeşil ot verimi ise $3377,33 \mathrm{~kg} / \mathrm{da}$ ile Vallivert çeşidinde saptanmıştır. İtalyan çimi çeşitlerinin yeşil ot verimi ortalama değeri $4028,31 \mathrm{~kg} \mathrm{da}^{-1}$ olarak tespit edilmiştir. Ülkemizin birçok bölgesinde İtalyan çimi ile ilgili çalışmalar yapılmış ve yeşil ot ile ilgili farklı değerler elde edilmiştir. İtalyan çimi yeşil ot verimine ait elde ettiğimiz değerler, Özdemir ve ark. [9]'nın 6997,3 ve 6645,5 $\mathrm{kg} \mathrm{da}^{-1}$ olarak ve Göktepe [10]'nin $5193 \mathrm{~kg} \mathrm{da}^{-1}$ olarak elde ettikleri verilerinden daha düşük olduğu tespit edilmiştir. Bazı araştırıcıların [11-15] yapmış oldukları çalışmalardan 2305-4179 kg $\mathrm{da}^{-1}$ arasında elde ettikleri değerlerden ve Özdemir [16]'in 2071,0 $\mathrm{kg} \mathrm{da}^{-1}$ olarak elde ettiği değerden yüksek olduğu tespit edilmiştir.

Tablo 1'e baktığımızda; en yüksek kuru ot verimi $1051,83 \mathrm{~kg} / \mathrm{da}$ ile Vallivert çeşidinden elde edilirken, bunu istatistiki olarak aynı grupta bulunan Devis (1044,20 kg da $\left.{ }^{-1}\right)$ ve Caramba $\left(1031,93 \mathrm{~kg} \mathrm{da}^{-1}\right)$ çeşitleri izlemiştir. En düşük kuru ot verimi ise $808,13 \mathrm{~kg} \mathrm{da}^{-1}$ ile Vespolini çeşidinden elde edilmiştir. Farklı İtalyan çimi çeşitlerinin kuru ot verimi ortalama değeri $967,58 \mathrm{~kg} \mathrm{da}^{-1}$ olarak tespit edilmiştir. İtalyan çimi kuru ot verimlerine ait daha önceki çalışmalarda; Alison ve ark. [17] $571 \mathrm{~kg}$ $\mathrm{da}^{-1}$ ile $416 \mathrm{~kg} \mathrm{da}^{-1}$ arasında, West ve ark. [18] $691 \mathrm{~kg} \mathrm{da}$ ${ }^{1}$ olarak elde ettiklerini bildirmektedirler. Elde ettiğimiz değerler diğer çalışmalardan elde edilen değerlerden daha yüksek tespit edilmiştir.

Tabloya baktığımızda; en yüksek ham protein oranı \%21,13 ile Vespolini çeşidinden elde edilirken, en düşük ham protein oranı ise $\% 14,63$ ile Vallivert çeşidinden elde edilmiştir. İtalyan çimlerinin ortalama ham protein oranları \%17,58 olarak tespit edilmiştir. İtalyan çimi ham protein oranına ait elde ettiğimiz değerler, Özdemir
İtalyan çimi çeşitlerine ait yeşil ot ve kuru ot verimleri ile ham protein oranı arasındaki farkın \%1 düzeyinde, ham protein veriminin ise $\% 5$ düzeyinde önemli olduğu saptanmıştır. ve ark. [9] \%13,20, Türk ve ark. [19] \%7,13, Kavut ve Geren [15] \%11,40, Özdemir [16] \%12,65, Peker [13] $\% 12,33$, Kara [20] \%14,96, Çolak [12] \%11,17, Çetin [21] \%12,9, Şimşek [22] \%11,58 olarak elde ettikleri değerlerden daha yüksek tespit edilmiştir.

Tablo 1 incelendiğinde; en yüksek ham protein verimi $179,57 \mathrm{~kg} \mathrm{da}^{-1}$ ile Baqueano çeşidinden elde edilirken, bunu istatistiki olarak aynı grupta bulunan Devis $(174,77$ $\left.\mathrm{kg} \mathrm{da}^{-1}\right)$ ve Caramba $\left(174,17 \mathrm{~kg} \mathrm{da}^{-1}\right)$ çeşitleri izlemiştir. En düşük ham protein verimi ise $154,00 \mathrm{~kg} \mathrm{da}^{-1}$ ile Vallivert çeşidinde elde edilmiştir. İtalyan çimi çeşitlerinin ham protein verim ortalama değeri $168,50 \mathrm{~kg}$ $\mathrm{da}^{-1}$ olarak tespit edilmiştir. Bursa'da tek yıllık çimin farklı varyeteleri ile yapılan bir denemede, ham protein veriminin $128,7 \mathrm{~kg} \mathrm{da}^{-1}$ olarak elde edildiği belirtilmiştir [23]. Elde ettiğimiz değerler diğer araştırmacıların elde ettiği değerlerden daha yüksek bulunmuştur. İtalyan çimi ham protein verimine ait elde ettiğimiz değerler, Özdemir ve ark. [9] 55,43 $\mathrm{kg} \mathrm{da}^{-1}$, Türk ve ark. [19] 37,6 $\mathrm{kg} \mathrm{da}^{-1}$, Kavut ve Geren [15] $48 \mathrm{~kg} \mathrm{da}^{-1}$, Özdemir [16] $49,30 \mathrm{~kg} \mathrm{da}^{-1}$, Kara [20] 67,70 kg da ${ }^{-1}$, Çolak [12] 36,12 $\mathrm{kg} \mathrm{da} a^{-1}$, Şimşek [22] 23,70 $\mathrm{kg} \mathrm{da}^{-1}$ olarak elde ediği değerlerden yüksek $\left(168,50 \mathrm{~kg} \mathrm{da}^{-1}\right)$ tespit edilmiştir.

Çalışmadan elde ettiğimiz veriler ile diğer araştırmacıların elde ettiği veriler arasındaki değişimlerin nedeni, kullanılan çeşitlerin birbirinden farklı olması, ekim alanlarının toprak ve iklim faktörlerinin birbirinden farklı olmasından ileri gelmektedir.

\subsection{ADF, NDF, SKM ve KMT Oranları (\%) ile NYD}

İtalyan çimi çeşitlerine ait NDF ve KMT oranları ile NYD arasındaki farkın \%1 düzeyinde, önemli olduğu, $\mathrm{ADF}$ ve SKM oranlarının ise istatistiki olarak önemsiz olduğu saptanmıştır. 
Tablo 2. İtalyan çimi çeşitlerinin ADF, NDF, SKM ve KMT oranları ile NYD ile ilgili ortalama değerler

\begin{tabular}{|l|l|l|l|l|l|}
\hline Çeşitler & ADF Oranı (\%) & NDF Oranı (\%) & SKM Oranı (\%) & KMT Oranı (\%) & NYD \\
\hline Devis & 40,23 & $57,63 \mathrm{C}^{* *}$ & 57,54 & $2,083 \mathrm{~B} * *$ & $92,92 \mathrm{~B}^{* * *}$ \\
\hline Baqueano & 38,33 & $58,90 \mathrm{BC}$ & 59,04 & $2,037 \mathrm{BC}$ & $93,24 \mathrm{~B}$ \\
\hline Caramba & 40,67 & $60,77 \mathrm{~B}$ & 57,22 & $1,977 \mathrm{CD}$ & $87,59 \mathrm{CD}$ \\
\hline Vallivert & 38,57 & $55,00 \mathrm{D}$ & 58,86 & $2,183 \mathrm{~A}$ & $99,55 \mathrm{~A}$ \\
\hline Trinova & 39,23 & $60,27 \mathrm{~B}$ & 58,34 & $1,990 \mathrm{C}$ & $90,06 \mathrm{C}$ \\
\hline Vespolini & 38,53 & $63,37 \mathrm{~A}$ & 58,88 & $1,893 \mathrm{D}$ & $86,44 \mathrm{D}$ \\
\hline Ortalama & $\mathbf{3 9 , 2 6}$ & $\mathbf{5 9 , 3 2}$ & $\mathbf{5 8 , 3 2}$ & $\mathbf{2 , 0 2 7}$ & $\mathbf{9 1 , 6 3}$ \\
\hline
\end{tabular}

**) İstatistiksel olarak \%1 (P $\leq 0,01)^{\prime}$ 'de önemlidir.

Tablo 2 incelendiğinde, İtalyan çimi çeşitlerine ait ADF oranı \%38,33-40,67 arasında değişim göstermiştir. Farklı İtalyan çimi çeşitlerinin ADF oranı ortalamaları \%39,26 olarak tespit edilmiştir. İtalyan çiminden elde ettiğimiz ADF oranları, Özdemir ve ark. [9] \%34,18, Kavut ve Geren [15] \%34,88, Özdemir [16] \%34,16, Türk ve ark. [19] \%33,30, Kara [20] \%31,72, Çolak [12] \%31,63, Çetin [21] \%34,9 olarak elde ettiği değerlerinden yüksek, Şimşek [22]'in \%39,66 olarak elde ettiği değerden ise düşük olduğu görülmüsştür.

Tablo 2'ye baktığımızda; en yüksek NDF oranı $\% 63,37$ ile Vespolini çeşidinden elde edilirmiştir. En düşük NDF oranı ise \%55,00 ile Vallivert çeşidinde saptanmıştır. Farklı İtalyan çimi çeşitlerinin NDF oranı ortalama değerleri \%59,32 olarak tespit edilmiştir. İtalyan çiminden elde ettiğimiz NDF değerleri, Özdemir ve ark. [9] \%48,30, Kavut ve Geren [15] \%48,08, Özdemir [16] $\% 48,10$, Kara [20] $\% 49,54$, Çolak [12] \%56,01, Türk ve ark. [19] \%57,30, Çetin [21]'in \%56,5 olarak elde ettikleri değerlerden yüksek olduğu görülmüştür. Şimşek [22]'in \%59,67 olarak elde ettiği değerden ise düşük olduğu belirlenmiştir.

Tablo 2 incelendiğinde; İtalyan çimi çeşitlerinin SKM oranı \%57,22-59,04 arasında değişim göstermiş̧ir. Farklı İtalyan çimi çeşitlerinin SKM oranı ortalama değerleri $\% 58,32$ olarak tespit edilmiştir. İtalyan çiminden elde ettiğimiz SKM oranları, Kara [20]'nın \%64,18, Çetin [21]'in \%61,6 olarak elde ettiği değerlerden düşük $(\% 58,32)$ elde edilmiştir. Farklı İtalyan çimi çeşitlerine ait en yüksek KMT oranı \%2,183 ile Vallivert çeşidinde elde edilmiştir. En düşük KMT oranı ise \%1,893 ile Vespolini çeşidinde saptanmıştır. İtalyan çimi çeşitlerinin KMT oranı ortalama değeri \%2,027 olarak tespit edilmiştir. Tablo 2'ye baktığımızda; en yüksek NYD 99,55 ile Vallivert çeşidinden elde edilmiştir. En düşük NYD 86,44 ile Vespollini çeşidinde saptanmıştır. Farklı İtalyan çimi çeşitlerinin NYD verimi ortalama değeri 91,63 olarak tespit edilmiştir. İtalyan çiminden elde ettiğimiz NYD, Kara [20] 120,98, Çolak [12]'1n 106,7 olarak elde ettiği değerlerden düşük $(91,63)$ elde edilmiştir.

\section{SONUÇ}

Ülkemizde kaba yem kaynaklarının verim ve kalite açısından yeterli düzeyde olmadığı, dolayısı ile diğer kaynakların yanında yem bitkilerinin tarla tarımı içerisindeki miktarını artırılması gerektiği öngörülmektedir. Ayrıca tarla tarımı içerisinde tarımı yapılan yem bitkilerinin bölgelere ve mikro iklim alanlarına uyumlu ve yüksek verim potansiyeline sahip çeşitlerin yetiştirilmesi gerekmektedir. Bingöl ekolojik koşullarında yapılan çalışmada; en yüksek yeşil ot verimi bakımından Trinova, Baqueano ve Caramba çeşitlerinin, ham protein verimleri bakımından Baqueano, Devis ve Caramba çeşitlerinin, en yüksek kuru ot verimi bakımından Vallivert, Devis ve Caramba çeşitlerinin, en düşük NDF bakımından Vespolini çeşidi ve kuru madde tüketimi oranı ve nispi yem değeri bakımından ise Vallivert çeşidinin ön plana çıktığı belirlenmiştir. Ancak bu çalışmanın daha uzun süre denenmesi gerektiği önem arz etmektedir.

\section{KAYNAKLAR}

[1] Elçi Ş (2005) Baklagil ve Buğdaygil Yem Bitkileri T.C. Tarım ve Köyişleri Bakanlığı, ISBN 975-407189-6 Mart Matbaasi- İstanbul s. 6-227

[2] Anonim (2018) http://www.torunoglutohum.com (erişim 20.02.2018)

[3] Avcıŏlu R, Açıkgöz E, Soya H, Tan A (2009) Yem Bitkileri Üretimi. (internet erişim): http://www.zmo.org.tr/resimler/ekler/18de4d2ec21 cfcb_ek.pdf?tipi=14\&sube $=$.[Ulașim:25/12/]

[4] Baytekin H, Kızılşimşek M, Demiroğlu G (2009) Çim ve Ayrık Türleri Editör: R. Avcıŏlu, R. Hatipoğlu, Y. Karadağ. Yem Bitkileri Genel Bölüm Cilt III. Tarım ve Köy İşleri Bakanlığı Tarımsal Üretim ve Geliştirme Genel Müdürlüğü, İzmir, s. 561-572

[5] Knowels F and Watkın J E (1967). A pratical Course in Agricultural Chemistry. Mc Millian Co. Ltd. New York, s. 37

[6] AOAC. Official Method of Analysis. 15th. edn. Association of Official Analytical Chemist, Washington, DC. USA. 1990

[7] Van Soest PJ, Robertson JB, Lewis BA. Methods for dietary fiber, neurtal detergent fiber and nonstarch polysaccharides in relation to animal nutrition. J. Dairy Sci. 1991;74(10):3583-3597

[8] Morrison JA. Hay and Pasture Management, Chapter 8.Extension Educator, Crop Systems Rockford Extension Center. 2003

[9] Özdemir S, Budaklı Çarpıcı E, Aşık BB (2019) Farklı Azot Dozlarının İtalyan Çiminin (Lolium multiflorum westerwoldicum Caramba) Ot Verimi ve Kalitesi Üzerine Etkileri, KSÜ Tarım ve Doğa Dergisi 22(1):131-137

[10] Göktepe AE (2015) Ruminantlar için karamba (Lolium multiflorum cv. Caramba) bitkisinin nispi yem değerinin ve in vitro sindirilebilirliğinin belirlenmesi, Ondokuz Mayıs Üniversitesi Sağlık 
Bilimleri Enstitüsü Hayvan Besleme ve Beslenme Hastalıkları Anabilim Dalı, Yüksek Lisans Tezi, Samsun, s. 28-33

[11] Kesiktaş M (2010) Çukurova Üniversitesi Fen Bilimleri Enstitüsü, Tarla Bitkileri Anabilim Dalı, Karaman'da farklı ekim zamanları azotlu gübre dozu uygulamalarının İtalyan çiminin (Lolium multiflorum westerwoldicum Caramba) yem verimine etkileri, Yüksek Lisans Tezi, s. 23-38

[12] Çolak E (2015) Azotlu gübre dozlarının İtalyan çimi (Lolium italicum L.) çeşitlerinin ot verimi, kalitesi ve bazı tarımsal özelliklerine etkisi, Doktora Tezi, Ankara s. 23-53

[13] Peker C (2013) Ankara koşullarında kırmızı üçgül (Trifolium incarnatum L.) ve İtalyan çimi (Lolium multiflorum cv. Caramba) karışım oranları ve ekim yöntemlerinin kaba yem verimine ve verimle ilgili özelliklere etkisi, Çukurova Üniversitesi, Fen Bilimleri Enstitüsü, Tarla Bitkileri Anabilim Dalı, Doktora Tezi, Adana, s. 51-142

[14] Çolak E, Sancak C (2016) Azotlu Gübre Dozlarının İtalyan Çimi (Lolium italicum L.) Çeşitlerinin Ot Verimi ve Bazı Tarımsal Özelliklerine Etkisi, Tarla Bitkileri Merkez Araştırma Enstitüsü Dergisi 25(1): 58-66

[15] Kavut YT, Geren H (2018) İtalyan çimi (Lolium multiflorum L.) + Tüylü fiğ (Vicia villosa L.) karışımlarında farklı hasat zamanları ve karışım oranlarının verim ve kalite özelliklerine etkisi, Mediterranean Agricultural Sciences 31(3): 283287

[16] Özdemir Ö (2017) Farklı azot dozlarının İtalyan çiminin (Lolium multiflorum westerwoldicum Caramba) ot verimi ve kalitesi üzerine etkileri Uludağ Üniversitesi, Fen Bilimleri Enstitüsü, Tarla Bitkileri Ana Bilim Dalı, Yüksek Lisans Tezi, Bursa, s. 1-35

[17] Alison MW, Barfîeld RE, Ashley JL (1989) Ryegrass cultivars for forage production. Herbage Abstracts 1989 Vol. 59 No. 12, p. 523

[18][18] West CP, Walker DW, Stoin HR, Bacon RK, Longer DE (1989) Forage yield and quality of small grains in Arkansas, Herbage Abstracts, 59(2): 53

[19] Türk M, Pak M, Bıçakçı E (2019) Farklı Azotlu Gübre Dozlarının Bazı Tek Yıllık Çim (Lolium multiflorum L.) Çeşitlerinin Ot Verimi ve Kalitesi Üzerine Etkileri, Ziraat Fakültesi Dergisi 14(2): 219-225

[20]Kara E (2016) Aydın koşullarında kışlık ara ürün olarak yetiştirilecek tek yıllık bazı baklagil ve buğdaygil yem bitkilerinin verim ve kalite özelliklerinin belirlenmesi, Adnan Menderes Fen Bilimleri Enstitüsü Tarla Bitkileri Anabilim Dalı, Yüksek Lisans Tezi, Aydın, s. 32-58

[21] Çetin R (2017) Tokat Kazova şartlarında tek yıllık çimde (Lolium multiflorum L.) azotlu gübrelemenin ot verimi ve kalitesine etkilerinin belirlenmesi, Gaziosmanpaşa Üniversitesi Fen Bilimleri Enstitüsü Tarla Bitkileri Ana Bilim Dalı, Yüksek Lisans Tezi, Tokat, s. 20-49

[22] Şimşek S (2015) Kırşehir koşullarında farklı Macar Fiği (Vicia pannonica Crantz) + İtalyan çimi
(Lolium multiflorum Lam.) karıșım oranlarının verim ve kalite üzerine etkilerinin belirlenmesi, Ahi Evran Üniversitesi Fen Bilimleri Enstitüsü, yüksek lisans tezi, Kırşehir, s. 2-43

[23] Başbuğ S (1990) Bursa şartlarında bazı çok yıllık ve tek y1llık buğdaygil yem, bitkilerinin ot verimi ve kalitesi üzerine araştırmalar, Uludağ Üniversitesi Fen Bilimleri Enstitüsü Yüksek Lisans Tezi, Bursa, s. $24-37$ 